\title{
Gospodarka oparta na wiedzy a globalne procesy geopolityczne
}

\section{DEINDUSTRIALIZACJA. WSTĘP DO BUDOWY NOWEJ GOSPODARKI}

Do lat 70. XX wieku kluczowym czynnikiem tworzenia bogactwa narodów był przemysł, w którym ciągły wzrost wydajności pracy opierał się na technologiach doskonalących te same lub podobne trwale produkowane wyroby: chemiczne, metalowe, narzędzia czy samochody. Drugim czynnikiem wzrostu było wykorzystanie korzyści wielkiej skali i stosowne do tego zachowania siły roboczej i konsumentów. Ta formacja gospodarcza, określana mianem fordyzmu, zaczęła się kształtować w USA po kryzysie 1929-1933, a w Europie Zachodniej po 1945 roku. Okazało się jednak, że możliwości tworzenia dobrobytu w ramach formacji fordowskiej były coraz mniejsze, a ponadto coraz droższe badania nad innowacjami w zakresie produktów przemysłowych przynosiły coraz mniejsze korzyści. Rozpoczął się spadek udziału przemysłu w tworzeniu dochodu narodowego i w strukturze zatrudnienia. I tak np. w latach 1975-1991 relatywnie największe spadki udziału przemysłu w tworzeniu dochodu narodowego odnotowano we Francji, z 36,1\% do 21,2\%, w Wielkiej Brytanii z 26,5\% do 21,4\%, we Włoszech z 27,7\% do 22,0\% i w USA, z 21,9 do 17,4\% (Klamut 1996, s. 169). W roku 1970 w krajach G7 (USA, Kanada, Japonia, Francja, Wielka Brytania, Niemcy, Włochy) pracownicy przemysłu stanowili 38,2\% ogółu zatrudnionych, natomiast w 2007 r. już tylko 23,7\%. W tym samym czasie udział przemysłu w zatrudnieniu zmniejszył się: w USA z 34,4\% do 19,8\%, we Francji z 39,2\% do 22,6\%, w Wielkiej Brytanii z 44,8\% do $22,2 \%$ (OECD 2009).

\section{OSOBLIWOŚCI NOWEJ GOSPODARKI}

Według OECD, termin „gospodarka oparta na wiedzy” (GOW) opisuje tendencje w państwach gospodarczo rozwiniętych, polegające na coraz większym znaczeniu wiedzy, informacji i wysokiego poziomu kwalifikacji oraz wzroście zapotrzebowania na dostęp do tych zasobów zarówno ze strony sektora prywatnego, jak i publicznego (OECD 2005). Inni 
autorzy, np. K. Porwit, zwracają uwagę na następujące cechy GOW: większy udział w PKB prac związanych z tworzeniem wiedzy i przetwarzaniem informacji, dynamiczny rozwój technologii informacyjnych i komunikacyjnych (ICT), zastosowanie ICT i związane z tym zmiany organizacyjne oraz tworzenie wiedzy naukowej jako odpowiedź na zapotrzebowanie praktyczne (Porwit 2001, s. 115-118). W trakcie dalszych rozważań termin „gospodarka oparta na wiedzy” będzie używany zamienne z terminem „nowa gospodarka”. Dla potrzeb tego opracowania przyjmę, że GOW polega na: zbliżeniu nauki do procesów tworzenia dóbr i usług, powstawaniu nowych wiedzochłonnych przemysłów, ekspansji sektora ICT oraz stosowaniu jego wytworów we wszystkich innych sferach działalności. Tworzenie się nowej gospodarki w państwach światowego centrum gospodarczego współwystępuje z deindustrializacją tych państw. Po stronie niektórych państw peryferyjnych mamy do czynienia z dość intensywną industrializacją. W efekcie tworzy się nowy światowy podział pracy, w którym światowe centrum gospodarcze coraz bardziej opiera się na gospodarce wiedzochłonnej, a państwa peryferyjne coraz bardziej się industrializują.

\section{NOWY ŚWIATOWY PODZIAŁ PRACY W PERSPEKTYWIE TEORII CENTRUM - PERYFERIE}

Centrum to państwa najbogatsze, dominujące w produkcji wyrobów wiodących, czyli wysoko przetworzonych, innowacyjnych, na ogół chronionych patentami. Peryferie to państwa najbiedniejsze, o dużym udziale sektora rolniczego i przemysłu produkującego proste i pracochłonne wyroby. Teoria centrum - peryferie, zwana także teorią rozwoju zależnego, narodziła się w środowiskach socjologów i ekonomistów Ameryki Łacińskiej w trakcie rozlicznych prób wyjaśnienia względnego niedorozwoju tego kontynentu (Prebisch 1959, Evers, Vogan 1987, Frank 1987, Cardoso, Faletto 2008, Yergin and Stanislaw 2002). W latach 80. I. Wallerstein rozszerzył teorię centrum - peryferie na światowy system gospodarczo-polityczny oraz wprowadził pojęcie półperyferii (Wallerstein 2007). Półperyferie to państwa uczestniczące w produkcji wyrobów wiodących, ale towarzyszy temu dość duży udział sektorów tradycyjnych. W trakcie dalszych rozważań dokonam rekonstrukcji i weryfikacji fragmentów teorii centrum - peryferie, dotyczących oceny korzyści i strat towarzyszących uczestnictwu w globalnej gospodarce rynkowej. Poniżej wypisane zostały główne hipotezy teorii centrum - peryferie, dotyczące interesującej nas problematyki.

Przekazywanie produkcji wyrobów przemysłowych do państw peryferii przeciwdziała obniżaniu się stopy życiowej i pośrednio sprzyja stabilności politycznej w państwach centrum. Światowy rynek finansowy służy eksploatacji peryferii. Spekulacje finansowe w centrum przyczyniają się do destabilizacji politycznej peryferii. Im większy poziom uczestnictwa państwa peryferyjnego w globalnej gospodarce, tym większe ponosi ono straty i tym większe są korzyści państw centrum.

\section{PRZEKAZYWANIE PRODUKCJI A STOPA ŻYCIOWA I STABILNOŚĆ POLITYCZNA W PAŃSTWACH CENTRUM}

W latach 80. i 90. w USA i w mniejszym stopniu w Europie Zachodniej likwidowane były stanowiska pracy relatywnie wysoko opłacane - w przemyśle. W USA redukcjom 
zatrudnienia towarzyszył spadek płac realnych, za wyjątkiem płac uzyskiwanych przez 1/5 najlepiej zarabiających. W efekcie spadała liczebność klasy średniej (osób uzyskujących średnie dochody) i wzrosła rozpiętość dochodów między najbogatszymi i całą reszta społeczeństwa (Thurow 1999, s. 39 i nast., Luttwak 2000, s. 102 i nast.). I tak np. w USA w latach 1980-1997 płaca godzinowa (w cenach z 1982 r.) w sektorze prywatnym poza rolnictwem spadła z 7,78 do 7,66 USD (Thurow 1999, s. 118). Jednocześnie trwał proces przekazywania produkcji przemysłowych dóbr konsumpcyjnych do krajów o niskich kosztach wytwarzania, co skutkowało spadkiem ich cen na rynku światowym (tab. 1).

Tab. 1. Wskaźnik cen wybranych trwałych dóbr konsumpcyjnych w miastach USA w sierpniu 2008 r. i w Wielkiej Brytanii na koniec 2007 r.

\begin{tabular}{|c|c|c|}
\hline \multicolumn{2}{|l|}{ USA, sierpień $2008 \mathrm{r}$. } & Wielka Brytania, koniec 2007 r. $\quad c$ \\
\hline $\begin{array}{r}\text { Przeciętne ceny ogółu dóbr } \\
\text { w latach } 1982-1984=100, \\
\text { ceny w sierpniu } 2008=218,88\end{array}$ & $a$ & $\begin{array}{l}\text { Indeks cen detalicznych ogółu dóbr } \\
\text { w Wielkiej Brytanii: } \\
\text { rok } 1987=100 \text {; rok } 2007=206,6\end{array}$ \\
\hline Hardware ICT + usługi & $10,0 \quad a$ & Brak danych \\
\hline Komputery osobiste z wyposażeniem & $92,9 \quad a$ & Domowe urządzenia elektryczne $-73,2$ \\
\hline Meble i wyposażenie sypialni & $124,8 \quad b$ & Brak danych \\
\hline Meble pokojowe, kuchenne i stołowe & $90,7 \quad b$ & 150,5 \\
\hline Naczynia kuchenne & $72,5 \quad b$ & Brak danych \\
\hline Zegary i artykuły dekoracyjne & $69,7 \quad b$ & Brak danych \\
\hline Odzież męska i chłopięca & $110,2 b$ & 95,8 \\
\hline Odzież damska i dziewczęca & $104,2 b$ & 67,0 \\
\hline Buty & $121,9 \quad b$ & 110,0 \\
\hline Zabawki & $66,4 \quad b$ & Odzież dziecięca $-88,8$ \\
\hline Sprzęt audio wideo & $102,6 \quad b$ & Brak danych \\
\hline Audio wyposażenie & $51,1 \quad b$ & Brak danych \\
\hline Inny sprzęt wideo & $19,9 \quad b$ & Brak danych \\
\hline
\end{tabular}

Źródła: $a$-Consumer Price Index 2008, Table 2, $b$-Consumer Price Index 2008, Table 3, $c$ - Focus on Consumer Price Indices 2008, Table 4.10

W innym dużym państwie centrum, w Niemczech, w latach 1991-2007 wskaźnik inflacji był niższy, ale tendencje w zakresie kształtowania się cen mebli, ubiorów i butów - takie same jak w USA i Wielkiej Brytanii (Consumer price index for Germany 2008). Zaspokojenie potrzeb w zakresie ubioru, urządzenia mieszkania, wychowania dzieci, sprzętu elektronicz- 
nego i telewizyjnego sukcesywnie tanieje w państwach centrum w ciagu ostatnich lat. Jak widać po cenach odzieży, największe korzyści z transferu produkcji do „fabryk świata” odniosły kobiety. Można sądzić, że znaczna część klasy robotniczej i średniej nie przejawia aspiracji do korzystania z wyrafinowanych usług czy ubierania się w luksusowych butikach. W odniesieniu do tych grup ewentualne obniżenie płac realnych wcale nie musiało skutkować wyraźnie niższym poziomem zaspokojenia podstawowych potrzeb gospodarstwa domowego (z wyjątkiem żywności). Można zatem sądzić, że poziom odczuwanych dolegliwości związanych z utratą pracy czy obniżeniem realnych dochodów gospodarstwa domowego był znacznie niższy niżby to wynikało ze statystyk.

Konkludując, należy stwierdzić, że przekazywanie produkcji wyrobów przemysłowych do państw peryferii przeciwdziała obniżaniu się stopy życiowej i pośrednio sprzyja stabilności politycznej w państwach centrum.

\section{CZY ŚWIATOWY RYNEK FINANSOWY SŁUŻY EKSPLOATACJI PERYFERII}

\section{CZY SPEKULACJE FINANSOWE W CENTRUM PRZYCZYNIAJĄ SIĘ \\ DO DESTABILIZACJI POLITYCZNEJ PERYFERII?}

Rozrosty funduszy inwestycyjnych i światowego rynku derywatów spowodowały, że giełdy papierów wartościowych stały się za małe. Około roku 2002 rozpoczął się podbój rynków towarowych przez bankowość inwestycyjną z właściwą jej mieszaniną pieniędzy wirtualnych i prawdziwych. Rozmiary tego roztworu finansowego mogły być dość dowolnie zwiększane poprzez tworzenie nowych derywatów i dlatego fundusze inwestycyjne uzyskały dużą moc sprawczą dla kształtowania cen na stosunkowo niewielkich rynkach surowcowych. $\mathrm{Na}$ giełdy towarowe, na których dotychczas dominowali producenci i konsumenci surowców, napłynęło dużo nowych kupców niezainteresowanych towarem, ale dynamiką jego cen. Ceny coraz bardziej zaczęły się odrywać od wielkości produkcji i faktycznego zapotrzebowania na nią.

W połowie roku 2008 ceny żywności na rynku światowym były o $83 \%$ wyższe niż trzy lata wcześniej (Kruger, Raupp 2008). Soja, która na początku 2006 r. kosztowała 200 USD za tonę, na początku 2008 r. kosztowała już 462 USD, kukurydza w tym samym czasie zdrożała ze 100 do 200 USD za tonę. Z kolei pszenica, która pod koniec roku 2005 kosztowała nieco ponad 100 USD, na początku 2008 r. kosztowała już 386 USD (Kiedy głodni... 2008, s. 36).

Pszenicy nie można przerobić na biopaliwa. Z tego względu wzrost zapotrzebowania na biopaliwa, stymulowany zwyżką cen ropy naftowej, nie wpływa na cenę pszenicy. Szacowano, że w latach 2006-2007 światowe zasoby pszenicy zmalały o $6 \mathrm{mln}$ ton do $619 \mathrm{mln}$ ton, czyli o 1\%, zaś jej spożycie konsumpcyjne spadło o 3\% do $108 \mathrm{mln}$ ton (World grain 2006-2007). Gdyby ceny pszenicy były wyłącznie efektem gry popytu i podaży te niewielkie spadki mogłyby skutkować co najwyżej 10-15\% wzrostem ceny. Jednak cena pszenicy wzrosła z nieco poniżej 200 USD w końcu 2006 roku do 386 USD w roku 2008 (Kiedy głodni... 2008, s. 36). Nie ulega najmniejszej wątpliwości, że stało się tak dzięki grze funduszy na zwyżkę cen.

Z informacji rządowych USA wynika, że w styczniu 2007 r. można było kupić na rynku USA baryłkę ropy Brent nawet za 48 USD. Podobnie wyglądały ceny na rynku światowym 
(Cena ropy USA 2004-2008). W ostatnim tygodniu lipca 2008 r. przeciętna cena ropy wyniosła w USA 134,44 USD i potem zaczęła spadać. Także i w tym przypadku wzrost miał w znacznym stopniu charakter spekulacyjny. Jedna z amerykańskich agencji rządowych zajmuje się m.in. obliczaniem popytu na ropę. Z jej wyliczeń wynika, że między I kwartałem 2007 a I kwartałem 2008 r. w Chinach wzrósł nieznacznie popyt na ropę, ale za to znacznie bardziej zmalał w USA - z 20,79 do 19,88 mln baryłek dziennie. Identycznie mierzony popyt światowy zmienił się w granicach błędu obliczeniowego z 85,78 do 85,85 (World petroleum (oil) demand 2004-2008). Mogła spaść podaż, ale tak się nie stało. Podaż ropy na rynku USA w okresie największego wzrostu cen, od stycznia 2007 do lipca 2008 r., mierzona przez agencję rządu USA, nawet nieco wzrosła - z 19,562 do 20,320 (USA petroleum supply 2004-2008). Podaż i popyt pozostały niezmienione, ale cena wzrosła ponad 2,5 razy, niewątpliwie głównie dzięki spekulacji.

Gorączka spekulacyjna cenami żywności zaowocowała dramatycznym pogorszeniem się warunków życiowych w różnych częściach globu. W ciągu kilku tygodni cena worka pszenicy w Mauretanii wzrosła dwukrotnie. Jednak w Wielkiej Brytanii artykuły spożywcze w 2007 roku zdrożały tylko o 6,6\%, podobnie jak w innych krajach europejskich (Kiedy głodni... 2008). Te dysproporcje wzrostu cen są, jak można sądzić, konsekwencją wspólnej polityki rolnej UE, która odgradza państwa europejskie od rynku światowego i tego, co się na nim dzieje. Na początku 2008 roku w siedmiu krajach (Haiti, Mauretania, Egipt, Mozambik, Senegal, Burkina Faso, Kamerun) doszło do zamieszek głodowych, w Kamerunie na początku marca zginęło w nich 100 osób (Kruger, Raupp 2008). Pogorszenie się sytuacji żywnościowej odnotowano w Afganistanie i Pakistanie, gdzie użyto wojska do ochrony konwojów z żywnością. W Afryce Północnej dość powszechnie zaczęto oskarżać rządy o nieudolność w zakresie zaopatrzenia ludności w żywność, z czym szedł w parze wzrost aktywności i popularności fundamentalistów islamskich (Kruger, Raupp 2008).

Jaki jest dowód na to, że fundusze inwestycyjne miały główny udział sprawczy w opisanych wyżej fluktuacjach cenowych? Kryzys finansowy 2008 roku spowodował znaczne osłabienie funduszy inwestycyjnych. Poniosły one straty na giełdach papierów wartościowych, co z kolei spowodowało wycofywanie wkładów przez udziałowców. Wraz ze zmniejszeniem się zasobów spadł potencjał cenotwórczy funduszy inwestycyjnych na rynkach towarowych. $\mathrm{Z}$ tego względu 8 października 2008 r. cena ropy Brent spadła do poziomu sprzed roku i osiągnęła wartość 86,1 USD za baryłkę (Interia.pl 2008), a w listopadzie 2008 r. można było kupić baryłkę ropy za mniej niż 50 USD (Onet.pl. Biznes 2008).

Podobnie działo się na innych rynkach towarowych. W drugiej połowie 2008 r. sytuacja na rynku żywnościowym pod względem podaży był taka sama jak w 2007 r., ale ceny zbóż zaczęły gwałtownie spadać. I tak np. pszenica kosztowała we wrześniu 2008 r. już tylko 188 USD za tonę (na początku roku 386 USD). Stanowi to dobitne potwierdzenie tego, że wzrost cen miał w znacznym stopniu spekulacyjny charakter. Spekulacyjny, czyli nie mający związku z realnym stosunkiem podaży i zapotrzebowania użytkowników. Czy oznacza to potwierdzenie tezy, że peryferie świata finansują rozwój USA i Europy? Państwa centrum rzeczywiście odnoszą korzyści wynikające z odgrodzenia się od konkurencji i podtrzymywania monopolizacji własnego rynku żywnościowego. Trudno zaprzeczyć, że choć operacje pieniądzem wirtualnym powodowały, że przeciętny Afrykanin płacił za chleb dwa razy więcej, to jednak ani przeciętny konsument, ani przeciętny producent afrykański raczej na pewno nie kupowali udziałów w funduszach inwestycyjnych. Może jednak być tak, że afrykańscy konsumenci żywości uczestniczą pośrednio w finansowaniu inwestycji w USA 
za pośrednictwem banków lokalnych, które ich obsługują. Jest to jednak raczej niemożliwe z racji braku kapitału. Np. w roku 1997 cały system bankowy Etiopii był mniejszy od systemu bankowego jednego z amerykańskich miast, liczącego 55 tys. mieszkańców (Stiglitz 2007, s. 43). To, że konsumenci żywności w krajach ubogich musieli więcej zapłacić za żywość, miało mniej więcej taki sam wpływ na stan funduszy inwestycyjnych jak gdyby płacili tyle samo co wcześniej, albo jeszcze mniej, czyli w zasadzie żaden. Opisaną sytuację należy raczej traktować jako przyczynianie się do stagnacji w rolnictwie państw peryferii niż pozyskiwanie kapitału.

Cytowane wcześniej wyliczenia udziału różnych państw w funduszach inwestycyjnych skłaniają do opinii, że gra spekulacyjna o zasoby na finansowanie nowej gospodarki rozegrała się między państwami bogatymi i bardzo bogatymi. Teza mówiąca o tym, że światowy rynek finansowy służy eksploatacji peryferii, zasługuje na odrzucenie. Natomiast teza głosząca, że światowy rynek finansowy przyczynił się do destabilizacji politycznej peryferii, została potwierdzona.

\section{BEZPOŚREDNIE KORZYŚCI I STRATY}

\section{Z UCZESTNICTWA W GLOBALNEJ GOSPODARCE}

Załóżmy, że dwaj aktorzy pożądają z podobną siłą jakiegoś dobra. Jego posiadanie jest dla nich korzystne. Jeżeli tak, to większe korzyści odniesie ten z nich, który w jednostce czasu uzyska więcej pożądanego dobra niż drugi. Nie ulega wątpliwości, że wzrost PKB jest dobrem powszechnie pożądanym przez rządy i obywateli. Przyjrzyjmy się teraz poziomowi uczestnictwa w światowym systemie gospodarczym. Pod uwagę weźmiemy państwa „fabryki świata", co do których da się jednoznacznie wykazać, że zmieniły swój poziom uczestnictwa w światowym systemie gospodarczym z minimalnego na wyraźnie większy. Na przełomie lat 70. i 80. do światowego sytemu gospodarczego włączyła się Chińska Republika Ludowa, zaś nieco później Wietnam. Indie zaczęły zrywać z protekcjonizmem w latach 80. Dla porównania zamieszczono informacje o państwach, których związek ze światową gospodarką rynkowa jest minimalny lub żaden (tab. 2).

$T a b$. 2. Średnioroczne przyrosty PKB w wybranych państwach centrum i „fabrykach świata” w latach 1971-1977 i 1982-2007 (\%)

\begin{tabular}{|l|c|c|}
\hline & $1971-1977$ & $1982-2007$ \\
\hline Chiny & 5,9 & 10,1 \\
\hline Wietnam & 4,4 & 6,9 \\
\hline Indie & 3,6 & 6,1 \\
\hline USA & 3,7 & 3,1 \\
\hline Europa Zachodnia & 3,2 & 2,1 \\
\hline Kuba & 5,9 & 2,0 \\
\hline Korea Północna & 8,6 & 0,2 \\
\hline
\end{tabular}

Źródło: United Nations 2008 
Przed włączeniem się Indii, Chin i Wietnamu do światowych relacji gospodarczych tempo wzrostu tych państw było mniejsze niż po włączeniu. W państwach centrum w tym samym czasie wystąiła tendencja odwrotna. Przejdźmy teraz do zadłużenia USA w Chinach, interpretowanego niekiedy jako finansowanie USA przez Chiny. Zadłużenie to pochodzi w głównej mierze stąd, że USA więcej kupują (w 2007 r. 232,7 mld USD) niż sprzedają w Chinach (w 2007 r. 69,38 mld USD) (Michalak 2008). Dla twórców teorii rozwoju zależnego neokolonialna eksploatacja peryferii przez centrum polegała na tym, że były one rynkiem zbytu dla rozwijającego się przemysłu centrum. Dużą dolegliwością państw peryferii, byłych kolonii Francji, Wielkiej Brytanii, był deficyt handlowy w wymianie z byłymi metropoliami. Jeżeli tak, to relacje między USA i Chinami mają neokolonialny charakter na niekorzyść USA. Jest to jednak wniosek absurdalny, mimo że logiczny. Pokazuje on wewnętrzną sprzeczność teorii centrum - peryferie w tych jej fragmentach, które dotyczą oceny stosunków gospodarczych między centrum i peryferiami. Nie ulega wątpliwości, że ekspansja gospodarcza Chin została zapoczątkowana bezpośrednimi inwestycjami zagranicznymi państw centrum. Wiodącą rolę odgrywały i nadal odgrywają tu USA, które są największym inwestorem w Chinach (w zakresie inwestycji bezpośrednich) - na sumę 56,58 miliardów USD (Michalak 2008). Jak widać, wkład USA we wzrost PKB w Chinach jest z pewnością większy niż wkład Chin we wzrost PKB w USA. Korzyści odnosi nie tylko państwo chińskie, ale i obywatele. Tylko w roku 2007 płace realne wzrosły w Chinach o 8\% (Gazeta Praca 2008). Dla porównania w USA w latach 1990-2006 płace realne wzrosły o $21 \%$, czyli mniej niż $2 \%$ rocznie. Wniosek: W miarę włączania się do gospodarki globalnej państwa peryferii odnosiły relatywnie większe korzyści bezpośrednie niż państwa centrum. Państwa pozostające poza światową gospodarką kapitalistyczną ponosiły straty.

\section{Literatura}

Amir S., 1974, Accumulation on a World Scale, Monthly Review Press, New York

Cardoso F.H., Faletto, E., 2008, Zależność a rozwój w Ameryce Eacińskiej. Próba interpretacji socjologicznej, Instytut Studiów Iberyjskich i Iberoamerykańskich UW i Muzeum Historii Polskiego ruchu Ludowego, Warszawa

Ceny ropy USA 2004-2008, http://tonto.eia.doe.gov/dnav/pet/hist/wtotusaw.htm

Consumer Price Index 2008, http://www.bls.gov/news.release/cpi.toc.htm

Evers T.T., Vogan P., 1987, „Dependencia”. Latynoamerykański wkład do teorii niedorozwoju, [w:]

R. Stempowski (wybór i wstęp), Ameryka Lacińska. Dyskusja o rozwoju, Czytelnik, Warszawa

FAO 2008, http://www.fao.org/docrep/011/ai473e/ai473e07.htm

Focus on Consumer Price Indices 2008, http://www.statistics.gov.uk/downloads/theme_economy/

Focus_on_CPI_November_2008.pdf Food Outlook 2008 FAO Price Index, http://www.fao.org/ docrep/011/ai474e/ai474e03.htm\#TopOfPage

Frank A.G. 1987, Rozwój niedorozwoju, [w:] R. Stempowski (wybór i wstęp), Ameryka Lacińska. Dyskusja o rozwoju, Czytelnik, Warszawa

„Gazeta Praca”, dodatek do „Gazety Wyborczej”, 21 sierpnia 2008

Kiedy glodni zjedza sytych, „Forum” 21.04-27.04.2008

Klamut M., 1996, Ewolucja struktury gospodarczej w krajach wysoko rozwiniętych, Wydawnictwo Akademii Ekonomicznej im. Oskara Langego we Wrocławiu, Wrocław

Kruger P.-A., Raupp J., 2008, Rewolucja za rogiem, „Suddeutsche Zeitung” 11.04., cyt. za „Forum” 21.04-27.04

Luttwak E., 2000, Turbokapitalizm, Wydawnictwo Dolnośląskie, Wrocław 
Mc Connell K., 2008, High Food Prices, Urban Migration Make It Hard to Help the Poor. U.S. officials talk of difficulty of feeding 35 million of the world's poor, Foreign Policy, http://www. america.gov/st/foraid- english/2008/April/20080417163323akllennoccm0.6278345.html

Michalak P., 2008, USA-Chiny: strategiczna wspótpraca w okresie zmian, http://www.psz.pl/tekst15310/Przemyslaw-Michalak-USA-Chiny-strategiczna-wspolpraca-w-okresie-zmian

OECD 2005 Knowledge-Based Economy. Definition; http://stats.oecd.org/glossary/detail.asp? $\mathrm{ID}=6864$

OECD 2009 Dataset: ALFS Summary tables, http://stats.oecd.org/WBOS/Index.aspx? DatasetCode= ALFS_SUMTAB\#

Onet.pl. Biznes 2008 Onet.pl. Biznes, 21 listopada, http://biznes.onet.pl /0,1866853,wiadomosci.html Porwit K., 2001, Cechy gospodarki opartej na wiedzy (GOW). Ich współczesne znaczenie i warunki skuteczności, [w:] A. Kukliński (red.), Gospodarka oparta na wiedzy. Wyzwania dla Polski XXI wieku, Wyd. KBN, Warszawa

Prebisch R., 1959, Commercial Policy in the Underdeveloped Countries, American Sociological Review, vol. 49(2), s. 251-273

Stiglitz J.E., 2007, Globalizacja, Wydawnictwo Naukowe PWN, Warszawa

Thurow C.L., 1999, Przyszłość kapitalizmu. Jak dzisiejsze sity ekonomiczne kształtuja świat jutra, Wydawnictwo Dolnośląskie, Wrocław

USA petroleum supply 2004-2008, http://tonto.eia.doe.gov/dnav/pet/hist/wrpupus2w.htm

Wallerstein I., 2007, Analiza systemów światów. Wprowadzenie, Wydawnictwo Akademickie DIALOG, Warszawa

World grain 2006-2007, http://www.world-grain.com/feature_stories.asp?ArticleID=84967

World petroleum (oil) demand 2004-2008 http://www.eia.doe.gov/ipm/demand.html

Yergin D. and Stanislaw J., 2002, Commending Heights, Free Press, New York

\section{Knowledge-based economy and global geopolitical processes}

Emergence of the knowledge-based economy coincides with the process of deindustrialization in the more wealthy countries. In some Asian countries, we can observe an intense process of industrialization. The main goal of this article is to verify the advantages and losses coming from participating in the global economy in the light of the "centre - periphery" theory. Transfer of industrial production to peripheral countries counteracts lowering of life-standards and indirectly favours political stability in the centre countries. Global financial market is a tool for the exploitation of peripheral countries. Financial speculations in the centre countries cause political destabilization in the peripheral countries. The higher the participation of a periphery country in the global economy, the higher the losses it suffers, and the higher the advantages for the centre countries.

Prof. dr hab. Janusz T. Hryniewicz

Uniwersytet Warszawski

EUROREG

e-mail: hrynie@poczta.onet.pl 